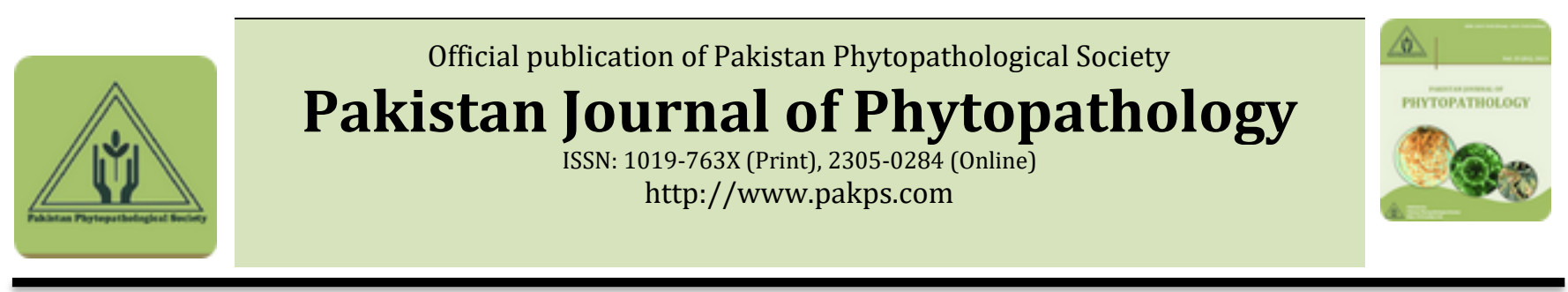

\title{
EFFECTIVE MANAGEMENT OF WHITE RUST (ALBUGO CANDIDA) OF RAPESEED THROUGH COMMERCIALLY AVAILABLE FUNGICIDES
}

\author{
aMuhammad Asif*, aMuhammad Atiq, aShahbaz T. Sahi, aSafdar Ali, bAhmed Nawaz, aYasir Ali, aAhmed Subhani, \\ aAmir Saleem \\ aDepartment of Plant Pathology, University of Agriculture Faisalabad-Pakistan \\ ${ }^{b}$ Department of Entomology, University of Agriculture Faisalabad-Pakistan
}

\section{A B S T R A C T}

Brassica napus (Rapeseed) affected by white rust is a major threat in Pakistan causing $60-90 \%$ yield losses. Two varieties of Brassica napus DGL and Oscar were sown in research area of department of Plant Pathology during 201617. Eight commercial fungicides were applied to check their efficacy to manage the white rust disease. Two concentrations $(0.25 \%$ and $0.50 \%)$ of each fungicide were applied on weekly interval with hand sprayer separately on each variety. Among all fungicides, Swing 72\% (Metalaxyl 8\% + Mancozeb 64\%) was found most effective in reducing the disease incidence. It reduced the disease incidence effectively up to $24.09 \%$ followed by Antracol (Propineb $70 \%$ ) $34.7 \%$. It is suggested that these fungicides can be used in the field for effective management of white rust of rapeseed.

Keywords: Brassica, Albugo candida, white rust, Chemicals management

\section{INTRODUCTION}

Brassica napus is the $2^{\text {nd }}$ most important oilseed crop. It has been cultivated in Asia, China, South Africa, Europe, and Canada since 2000 BC (Warwick et al., 2006; Yao et al., 2012). It is cultivated on an area of 25 million hectares with 46 million tons' production worldwide (FAO, 2004). In Pakistan, it is cultivated on an area of 193.6 thousand hectares and its production of seed and oil content is 181 and 56 thousand tons respectively in 2015 (PODB, 2015) and it fulfills the $17 \%$ of oil requirement of Pakistan which is subjected to many diseases. Among all diseases, White Rust (WR) is the most destructive disease of Brassica in hot and humid areas of Pakistan caused by Albugo candida (Armstrong, 2007; Abbas et al., 2008)). It causes 20-90\% yield losses throughout the world (Kumar and Kalha, 2005; Mishra et al 2009). The candidum (candida) specie of genus

Submitted: August, 29, 2017

Revised: December, 08, 2017

Accepted for Publication: December 20, 2017

* Corresponding Author:

Email: m.asifssa138@gmail.com

(C) 2017 Pak. J. Phytopathol. All rights reserved.
Albugo causing white rust was first reported by Gmelin (1792) while in Pakistan it was reported from FATA and Bajur Agency (Ahmad et al., 1997). It is an obligate parasite and can be survived by means of producing oospores in infected plants parts and in soil for more than 20 years (Gupta et al., 2004; Hina et al., 2014). Optimum temperature for effective infection is $12-22^{\circ} \mathrm{C}$ and relative humidity (RH) $60-90 \%$ (Sullivan et al., 2002). It contains different beneficial chemicals like amino acids, folate, glucosinolate, carotenoids, ascorbic acid, tocopherols, phenolic, sugar, minerals and vegetable oil content. These compounds play vital role in human, animal's nutrition as well as play significant role in the survival of plant (Jahangir et al., 2009; Huber et al., 2009; Rossetto et al., 2013). Mainly it produces two types of infection: local and systemic. Local infection is characterized by the formation of raised creamy white sporangial pustules on the undersurface of leaves, on tender shoots. The affected tissue turns necrotic and dies. Systemic infection is usually seen in young inflorescences and terminal leaves. It stimulates hypertrophy and hyperplasia resulting in abnormal 
swelling and malformation of the affected organs. Floral organs turn green, become greatly enlarged and distorted, and seed formation is prevented (Saharan and Mehta, 2002; Mishra et al., 2009).

There are many management strategies available against the white rust disease like resistant varieties, crop rotation, chemical and biological control, and cultural practices. Resistant cultivars are the best option to control the disease as they are eco-friendly, locally adapted to the environment, and durable. Due to unavailability of exotic resistant germplasm farmer has to cultivate susceptible varieties. Different plant extracts are also used to manage this disease (Nwachukwu and Umechuruba, 2001). These plant extracts are environment friendly which have been successfully used to manage this disease. Use of resistant varieties is most cost effective method and it may limit the use of fungicides. But the emergence new races of pathogen overcome resistance genes in currently grown cultivars (Fravel et al., 2003). So, another rapid and effective way of controlling white rust disease is an application of fungicides. As other alternative methods such as biological control, plant extracts, and agricultural practices are becoming less effective. Somehow these methods are time consuming and labor requiring. There are chances of adulterated formulations of biological formulation which will result in loss of money and crop (Abada et al., 2008). That's why, these are necessary to maintain the potential yield as fungi produces countless spores to withdraw nutrients from the plant (Lenard and Nathan, 2006). When disease suddenly appear, it is very difficult for a farmer either to apply different organic formulations or totally uproot plants. Chemicals will protect by forming layer on leaves surface while some have ability to penetrate the system and help the plant to reverse the biochemical changes induced by the pathogen. These are rapid and quick remedy and easy to apply in case of sudden outburst of disease. Many field trials of different concentrations of fungicides were resulted in $30-65 \%$ disease control in India. Seed treatment and foliar spraying of different fungicides concentrations were tested on multiple varieties to validate them as cost effective (Rathi and Singh, 2010). Application timing of fungicides play critical role in controlling WR disease especially in late sown crop. It is being suggested by Mehta, Khangura and Sokhi (2000) that two to three foliar sprays of a fungicide will be enough to manage this disease.

Disease incidence fluctuates with cropping seasons depending on the prevalent weather conditions. That leads farmers to follow different strategies of control. Mostly fear of farmer is losing their crop yield which force them to apply abundant fungicides as a preventive measure at calendar based spraying intervals. Some other farmers apply fungicides based on their experience and weather forecast conditions. The current strategies might contribute to increase pesticide concentration in the surface waters of the region (Konstantinou et al., 2006). Main objective of present study was to evaluate the efficiency of chemicals against white rust pathogen to minimize its yield losses under field conditions.

\section{MATERIALS AND METHODS}

Evaluation of Fungicides in Field Conditions: The experiment was conducted in the research area of Department of Plant Pathology, University of Agriculture Faisalabad in December 01, 2016. Two varieties of brassica (DGL and Oscar) were collected from Oilseed Research Institute, Ayub Agricultural Research Institute (AARI), Faisalabad. These varieties were planted on flat bed surface under Randomized Complete Block Design (RCBD) with plant to plant $(\mathrm{P} \times \mathrm{P})$ distance $45 \mathrm{~cm}$ and bed to bed $(\mathrm{B} \times \mathrm{B})$ distance 75 $\mathrm{cm}$ with three replications of each variety. The size of the plot was adjusted to $10 \mathrm{ft} \times 10 \mathrm{ft}$ with four rows. All the cultural practices were performed to keep the crop in healthy condition with the application of standard doses of fertilizers. Eight commercial fungicides (Rally 40\% WP (Myclobutanil 40\%), Chlorostrobin (Azoxystrobin 5.4\%+Chlorothalonil 45\%), Alliette 80\% WP (Fosetyli-Aluminium 80\%), Success 70\% WP (Metalaxyl 8\% + Chlorothalonil 64\%), Swing 72\% (Metalaxyl 8\% +Mancozeb 64\%), Cytrol 75\% (Thiophanate-methyle 35\% + Chlorothalonil 40\%), Antracol (Propineb 70\%) and Score 250 EC (Difenconazole 250EC) taken from market. Two concentrations $0.25 \%$ and $0.50 \%$ were made by dissolving $25 \mathrm{mg}$ and $50 \mathrm{mg}$ in $100 \mathrm{ml}$ water. Hand sprayer (HECHT-401, Model: HT-401) was used to apply the foliar concentration of spray on each row of variety. Untreated rows of each varieties/lines in each block served as check/control. First spray of the fungicides was applied by Hand sprayer (HECHT-401, Model: HT-401) one month after the crop sowing just 
after the appearance of initial symptoms in the field. First spray was carried out immediately after the appearance of the disease symptoms and repeated after seven days according to the treatment plan. Disease ratings were recorded by visual observations at the initiation of primary symptoms disease and continued till the physical maturity of the crop or when the leaves became necrotic due to fungal attack. Data was collected on weekly basis using following method:

$$
\text { Disease incidence }(\%)=\frac{\text { No. of infected plants }}{\text { Total No. of plants }} \times 100
$$

Statistical Analysis: Data was analyzed by analysis of variance and treatments were compared by using Least Significant Difference (LSD) test (Steel et al., 1997). All the statistical tests were performed by using SAS statistical software (SAS institute, 1990).

\section{RESULTS}

All the fungicides used in this study exhibited significantly effective results to manage the white rust disease. Among all fungicides, Swing 72\% (Metalaxyl 8\% + Mancozeb 64\%) reduced the disease incidence very efficiently after application of both concentrations in both weeks. In addition to this, the results of Swing 72\% (Metalaxyl 8\% + Mancozeb 64\%) were more prominent on Oscar with the mean values of disease incidence
$19.977 \%, 17.157 \%$ and $14.64 \%$. It suggested that second concentration of this fungicide is most effective. Moreover the $0.50 \%$ concentration of Antracol (Propineb 70\%) showed better results as compared to control. Similarly, both concentrations of Score 250 EC (Difenconazole 250EC) resulted in decreasing the disease incidence first but later it gradually increased. Although the disease was suddenly enhanced but it was less as compared to control. Moreover, maximum disease incidence on both varieties was expressed by Rally 40\% WP (Myclobutanil 40\%) followed by Chlorostrobin (Azoxystrobin 5.4\%+Chlorothalonil 45\%), Alliette $80 \%$ WP (Fosetyli-Aluminium 80\%), Success 70\% WP (Metalaxyl 8\% + Chlorothalonil 64\%) and Score 250 EC (Difenconazole 250EC) respectively. Among all Swing 72\% (Metalaxyl 8\% + Mancozeb 64\%) ranked first followed by Antracol (Propineb 70\%) and Success 70\% WP (Metalaxyl 8\% + Chlorothalonil 64\%). In addition, Most least effective fungicide was found Cytrol 75\% (Thiophanate-methyle 35\% + Chlorothalonil 40\%) followed by Chlorostrobin (Azoxystrobin 5.4\%+Chlorothalonil 45\%), Rally 40\% WP (Myclobutanil $40 \%$ )and Score 250 EC (Difenconazole 250EC). Although they reduced the disease as compare to control but they can not be recommended for quick remedy (Table 6).

Table 6. Evaluation of interaction of treatments with concentrations, weeks and Varieties ( $\mathrm{TxWxVxC}$ ) against white rust of brassica.

\begin{tabular}{|c|c|c|c|c|c|c|c|c|c|}
\hline \multirow{2}{*}{\multicolumn{2}{|c|}{ Treatments }} & \multicolumn{8}{|c|}{ Disease incidence \% } \\
\hline & & \multicolumn{4}{|c|}{ After Week 1} & \multicolumn{4}{|c|}{ After Week 2} \\
\hline $\mathrm{Sr}$ & & Conc. 1 & Conc. 2 & Conc. 1 & Conc. 2 & Conc. 1 & Conc. 2 & Conc. 1 & Conc. 2 \\
\hline 2 & Chlorostrobin & $42.757 \mathrm{pq}$ & $41.023 \mathrm{tu}$ & $34.327 \mathrm{abc}$ & $48.523 \mathrm{de}$ & $48.50 \mathrm{ef}$ & $43.763 \mathrm{mno}$ & $30.790 \mathrm{fg}$ & $34.977 \mathrm{a}$ \\
\hline 3 & Allette & $33.377 \mathrm{de}$ & $45.483 \mathrm{ijk}$ & $29.263 \mathrm{ij}$ & 41.803 rst & $38.317 \mathrm{wx}$ & $39.423 \mathrm{v}$ & $33.910 \mathrm{bcd}$ & $42.757 \mathrm{pq}$ \\
\hline 4 & Success & $38.283 \mathrm{wx}$ & $44.297 \mathrm{~lm}$ & $39.023 \mathrm{vw}$ & $45.077 \mathrm{jkl}$ & $46.257 \mathrm{hi}$ & 33.527 cde & $42.157 \mathrm{qr}$ & $47.623 \mathrm{efg}$ \\
\hline 7 & Antracol & 38.713 vwx & $31.633 \mathrm{f}$ & 34.263abcd & $28.877 \mathrm{j}$ & $40.683 \mathrm{u}$ & $26.730 \mathrm{z}$ & $41.597 \mathrm{stu}$ & $25.130 \mathrm{l}$ \\
\hline 8 & Score & $32.827 \mathrm{e}$ & $30.610 \mathrm{gh}$ & $48.203 \mathrm{ef}$ & $47.570 \mathrm{~g}$ & $36.967 \mathrm{z}$ & $34.283 \mathrm{abcd}$ & $47.100 \mathrm{~h}$ & $45.073 \mathrm{jkl}$ \\
\hline \multirow[t]{2}{*}{9} & Control & $68.7 \mathrm{a}$ & $68.7 \mathrm{a}$ & $68.7 \mathrm{a}$ & $68.7 \mathrm{a}$ & $63.3 \mathrm{~b}$ & $63.3 \mathrm{~b}$ & $63.3 \mathrm{~b}$ & $63.3 \mathrm{~b}$ \\
\hline & & LSD & & & & 0.946 & & & \\
\hline
\end{tabular}

C $1=0.25 \%$, C $2=0.50 \%$ (Conc. $=$ concentration)

* Mean values in a column sharing similar letters do not differ significantly as determined by the LSD test $(\mathrm{P} \leq 0.05)$.

\section{DISCUSSION}

Our results were supported by the results of Rathi et al., (2009) in which they executed the foliar application of Ridomil MZ-72 WP containing active ingredient of $8 \%$ Metalaxyl and 64\% Mancozeb @ 2g/l to control the white rust disease. Ridomil MZ-72 WP significantly reduced the disease incidence ranging from 64 to $30 \%$. Our findings are prominently similar with reduction range of $40 \%$ in disease after the twice application of swing @ 2.5g/l.

Similarly, Rohilla et al., (2001) evaluated foliar spray of Ridomil MZ-72 WP which effectively reduced Albugo candida inoculum in open field conditions. They found it helpful in reducing the disease incidence quickly on 
brassica. They used Apron 35-SD (Propineb) as a foliar spray mixed with Ridomil MZ-72. This combination resulted in significant reduction of white rust disease. Our results support the findings of Kuyucuklu and Ozer, (1994), they conducted an experiment to determine the efficacy of fungicides and concluded that Antracol $50 \mathrm{WP}$ (propineb 70\%), Polyram DF (metiram complex 80\%) and Curzeb 50 WP (mancozeb 45\% + cymoxanil 5\%) gave 60,74 and $80 \%$ efficacy, respectively.

These findings were quite match able to Talkuder et al., (2012). They also conducted similar experiment on Ridomil gold 68 WP (Chlorothalonil + Mefenoxam) @ $0.2 \%$, Contaf 25 EC (Triazole) @ 0.1\%, and X-tra care 300 EC (myclobutanil) \% $0.05 \%$ to control white rust (Albugo occidentalis) of red amaranth (Amaranthus spp.). Among these Ridomil gold was found most effective one to control white rust.

Meena et al., (2011) conducted different experiments to check efficiency of Mancozeb against white rust disease of Brassica. Its results support the results of this study. After different trials she demonstrated the lowering of disease incidence up to $64 \%$ and 19\%. Meena et al., (2011) showed that chemical fungicides in combination with Eco-friendly products such as T. harzianum and Pseudomonas fluorescence will give better results against WR. Khan et al., (2007) findings on different fungicides and their combinations are actively in the favor of our research theme. They evalutes Bavistom, Topsin $M$ and Ridomil MZ were evaluated and compared with other four commercial fungicides like Captaf, Indofil M-45, Indofil Z-78 and Thiram white rust. Ridomil MZ was found significantly effective controlling disease up to $32 \%$. Topsin $\mathrm{M}$ and Ridomil formulations are similar to Swing 72\% (Metalaxyl 8\% + Mancozeb 64\%) 72\% (Metalaxyl 8\% + Mancozeb 64\%) and Antracol (Propineb 70\%) (Propineb 70\%) and support the results investigated by this research.

\section{REFERENCES}

Abada, K., M. R. Hilall and S. Mostafa. 2008. Induced resistance against powdery mildew in cucumber. Journal of Biodiversity and Environmental Sciences, 3: 45-56.

Abbas, S., K. I. Farhatullah, K. B. Marwat and I. Munir. 2008. Molecular and biochemical assessment of Brassica napus and indigenous campestris species. Pakistan Journal of Botany, 40: 2461-2469.

Ahmad, H. N., R. Perveen, S. Chohan, G. Yasmeen, M. A. Mehmood and W. Hussain. 2014. Screening of
Canola Germplasm against Albugo Candida and Its Epidemiological Studies. Pakistan Journal of Phytopathology, 26: 169-173.

Ahmad, M., A. Russell and D. McNeil. 1997. Identification and genetic characterization of different resistance sources to ascochyta blight within the genus Lens. Euphytica, 97: 311-315.

Armstrong, T. 2007. Molecular detection and pathology of the oomycete Albugo candida (white rust) in threatened coastal cresses. Science \& Technical Pub., Department of Conservation.

FAO. 2004. Food and agriculture organization of the United Nations (FAO). United Nations.

Fravel, D., C. Olivain and C. Alabouvette. 2003. Fusarium oxysporum and its biocontrol. New Phytologist, 157: 493-502.

Gmelin, J. 1792. Systema Naturae, 2 (2). GE, Beer, Leipzig.

Gupta, K. and G. Saharan. 2002. Identification of pathotypes of Albugo candida with stable characteristic symptoms on Indian mustard. Journal of Mycology and Plant Pathology (India).

Huber, L. S., R. Hoffmann-Ribani and D. B. RodriguezAmaya. 2009. Quantitative variation in Brazilian vegetable sources of flavonols and flavones. Food Chemistry, 113: 1278-1282.

Institute, S. 1990. SAS Language: Reference: Version 6. Sas Inst.

Jahangir, M., H. K. Kim, Y. H. Choi and R. Verpoorte. 2009. Health-Affecting Compounds inBrassicaceae. Comprehensive Reviews in Food Science and Food Safety, 8: 31-43.

Khan, Z., Y. Kim, S. Kim and H. Kim. 2007. Observations on the suppression of root-knot nematode (Meloidogyne arenaria) on tomato by incorporation of cyanobacterial powder (Oscillatoria chlorina) into potting field soil. Bioresource Technology, 98: 69-73.

Konstantinou, I. K., D. G. Hela and T. A. Albanis. 2006. The status of pesticide pollution in surface waters (rivers and lakes) of Greece. Part I. Review on occurrence and levels. Environmental Pollution, 141: 555-570.

Kumar, S. and C. Kalha. 2005. Evaluation of rapeseedmustard germplasm against white rust and alternaria blight. Annals of Biology (India).

Kuyucuklu, K. and N. Ozer. 1994. A research on downy mildew disease on melons in Corlu District and its surroundings. Journal of Tekirdag Agricultural 
Faculty, 3: 27-34.

Leonard, G. and N. Reigner. 2006. How the use of fungicides has benefited US agriculture. Outlooks on Pest Management, Crop Life Foundation, Washington, DC, U.S.A.

Meena, S. S., K. S. Brar, J. S. Chauhan, P. D. Meena, P. S. Sandhu, R. P. Awasthi, A. S. Rathi, Kumar, Ashok, J. C. Gupta and S. J. Kolte. 2011. Biplot analysis of Brassica genotypes for white rust disease severity under aided epiphytotic conditions in India. Proceedings of 13th International Rapeseed Congress: $1201-1204$.

Miranda Rossetto, M. R., T. M. Shiga, F. Vianello and G. P. Pereira Lima. 2013. Analysis of total glucosinolates and chromatographically purified benzylglucosinolate in organic and conventional vegetables. LWT - Food Science and Technology, 50: 247-252.

Mishra, K. K., S. J. Kolte, N. I. Nashaat and R. P. Awasthi. 2009. Pathological and biochemical changes in Brassica juncea(mustard) infected withAlbugo candida(white rust). Plant Pathology, 58: 80-86.

Nwachukwu, E. O. and C. I. Umechuruba. 2010. Antifungal
Activities of Some Leaf Extracts on Seed-borne Fungi of African Yam Bean Seeds, Seed Germination and Seedling Emergence. Journal of Applied Sciences and Environmental Management, 5.

PODB. 2014-15. Economic Survey of Pakistan. Federal Bureau of Statistics, MINFAL Islamabad.

Rathi, A. and D. Singh. 2009. Integrated management of Alternaria blight and white rust in Indian mustard. Proceedings of 16th Australian Research Assembly on Brassicas on changing foods, changing climate, changing canola held at Ballarat.

Rohilla, R., R. Singh, U. Singh, R. Singh, E. Duveiller and H. Singh. 2001. Recent advances in the management of plant disease using chemicals.

Saharan, G. S. and N. Mehta. 2002. Fungal diseases of rapeseed-mustard. Diseases of field crops.

Steel, R. G., J. H. Torrie and D. A. Dickey. 1997. Principles and procedures of statistics: A biological approach. McGraw-Hill.

Sullivan, M. J., J. P. Damicone and M. E. Payton. 2002. The Effects of Temperature and Wetness Period on the Development of Spinach White Rust. Plant Disease, 86: 753-758. 